\title{
Genetic evaluation of suspected osteogenesis imperfecta (OI)
}

Peter H. Byers, $M D^{1}$, Deborah Krakow, $M D^{2}$, Mark E. Nunes, $M D^{3}$, and Melanie Pepin, $M S, C G C^{1}$

Key Words: Osteogenesis imperfecta, brittle bone disease, type I collagen, COL1A1, COL1A2, non-accidental

injury, prenatal diagnosis, laboratory testing

\begin{abstract}
Disclaimer: This guideline is designed primarily as an educational resource for medical geneticists and other health care providers to help them provide quality medical genetic services. Adherence to this guideline does not necessarily assure a successful medical outcome. This guideline should not be considered inclusive of all proper procedures and tests or exclusive of other procedures and tests that are reasonably directed to obtaining the same results. In determining the propriety of any specific procedure or test, the geneticist should apply his or her own professional judgment to the specific clinical circumstances presented by the individual patient or specimen. It may be prudent, however, to document in the patient's record the rationale for any significant deviation from this guideline.
\end{abstract}

Osteogenesis imperfecta (OI) is probably the most common genetic form of fracture predisposition. The term OI encompasses a broad range of clinical presentations that may be first apparent from early in pregnancies to late in life, reflecting the extent of bone deformity and fracture predisposition at different stages of development or postnatal ages. Depending on the age of presentation, OI can be difficult to distinguish from some other genetic and nongenetic causes of fractures, including nonaccidental injury (abuse). The strategies for evaluation and the testing discussed here provide guidelines for evaluation that should help to distinguish among causes for fracture and bone deformity.

\section{OVERVIEW}

Osteogenesis imperfecta (OI) is an inherited disorder of connective tissue characterized by bone fragility and fractures; other clinical features include blue sclerae, adult onset hearing loss and joint laxity. ${ }^{1}$ The severity ranges from lethal in the perinatal period to occasional fracture. Inheritance is generally autosomal dominant but new mutations are common and recessive inheritance occurs. In most instances (about 90\%), a mutation in one of the two genes (COL1A1 and COL1A2) that encode the chains of type I collagen, the major protein of bone, accounts for the phenotype. ${ }^{2}$ Less frequently, yet-to-be-identified genes are responsible. ${ }^{3-5}$ The diagnosis of $\mathrm{OI}$ is considered at different times: during fetal development, at birth, in childhood, or less often in adults. Regardless of the time at which the diagnosis is suspected, the first line of evaluation is a detailed medical history, family history, physical examination, appropriate radiographs and routine lab testing. If these do not

From the ${ }^{1}$ University of Washington, Seattle, WA, ${ }^{2}$ Cedars-Sinai Medical Center, Los Angeles, CA, ${ }^{3}$ Inova Fairfax Hospital for Children, Fairfax, VA. Approved by the Board of Directors March 16, 2005 Go to www.geneticsinmedicine.org for a printable copy of this document. DOI: 10.1097/01.gim.0000223557.54670.aa lead to diagnosis, then specialized genetic testing is warranted. We have organized the approach to diagnosis of $\mathrm{OI}$ in an agespecific fashion.

\section{Ol: IDENTIFICATION IN PREGNANCY}

OI may be suspected in a fetus at different gestational ages, depending on whether the clinical question is raised by family history or by routine ultrasound examination.

\section{In the presence of a positive family history of 0 I}

The fetus is usually at a $50 \%$ risk for OI when a parent has OI. When only a sibling has OI, the risk varies from $0 \%$ to $50 \%$, reflecting the proportion of parental gametes that have the mutation in a mosaic pattern. ${ }^{6}$ Both targeted ultrasound examinations and laboratory testing (protein-based or DNAbased) can be considered.

Fetal Ultrasound Examination: Ultrasound examination, trans-abdominal (TA) or trans-vaginal (TV $)^{7,8}$ should be offered as early as 13-14 weeks gestation for a pregnancy at risk for the severe, lethal form of OI (OI type II) and 16-20 weeks for one at risk for OI type III. Ultrasound identification of OI type I and OI type IV has been reported infrequently after 20 weeks gestation on the basis of fetal fracture, but cannot be relied upon. ${ }^{8}$ (Table 1, Fig. 1 )

\section{Laboratory Testing}

For the pregnancy at risk for most forms of OI (OI type II, III or IV) on the basis of family history, biochemical analysis of type I collagen synthesized by cultured chorionic villi cells (CVS) can be offered if collagen screening studies have been completed on the affected parent or a previous affected infant and shown to be abnormal. ${ }^{6}$ The time from CVS biopsy to final diagnosis is about 3-4 weeks. The same biochemical assay can- 
Table 1

Ultrasound identification of OI during pregnancy (Listed in order of first ultrasound detection)

\begin{tabular}{|c|c|c|c|c|}
\hline Type & Genetics & Clinical findings & Ultrasound findings & $\begin{array}{l}\text { First ultrasound } \\
\text { detection }\end{array}$ \\
\hline $\begin{array}{r}\text { OI II lethal } \\
\text { perinatal }\end{array}$ & $\begin{array}{l}\text { Autosomal } \\
\text { dominant }\end{array}$ & $\begin{array}{l}\text { Lethal perinatal type: Undermineralized skull, } \\
\text { micromelic bones, "beaded" ribs on x-ray, } \\
\text { bone deformity, platyspondyly }\end{array}$ & $\begin{array}{l}\text { Undermineralization, broad, crumpled } \\
\text { and shortened limbs, thin beaded } \\
\text { ribs, fractures, angulation or bowing } \\
\text { of long bones, normal appearing } \\
\text { hands, deformable calvarium }\end{array}$ & $\geq 14$ wks \\
\hline OI III & $\begin{array}{l}\text { Autosomal } \\
\text { dominant }\end{array}$ & $\begin{array}{l}\text { Progressively deforming type: Moderate } \\
\text { deformity of limbs at birth, sclerael hue } \\
\text { varies, very short stature, dentinogenesis } \\
\text { imperfecta (DI) }\end{array}$ & $\begin{array}{l}\text { Thin ribs, short limbs, fractures, } \\
\text { undermineralized skull, long bone } \\
\text { length falls away from normal 16-18 } \\
\text { weeks }\end{array}$ & $\geq 18$ wks \\
\hline OI IV & $\begin{array}{l}\text { Autosomal } \\
\text { dominant }\end{array}$ & $\begin{array}{l}\text { Normal sclerae, mild/moderate limb deformity } \\
\text { with fracture, variable short stature, } \\
\text { DI, some hearing loss }\end{array}$ & $\begin{array}{l}\text { Rarely, long bone bowing and/or } \\
\text { fracture }\end{array}$ & $\begin{array}{l}\text { After } 20 \text { wks but } \\
\text { not common }\end{array}$ \\
\hline OI I & $\begin{array}{l}\text { Autosomal } \\
\text { dominant }\end{array}$ & $\begin{array}{l}\text { Fractures with little or no limb deformity, blue } \\
\text { sclerae, normal stature, hearing loss, DI }\end{array}$ & Rarely, long bone bowing or fracture & $\begin{array}{l}>20 \text { wks but } \\
\text { not common }\end{array}$ \\
\hline OI V & $\begin{array}{l}\text { Autosomal } \\
\text { dominant }\end{array}$ & $\begin{array}{l}\text { Similar to OI IV plus calcification of } \\
\text { interosseous membrane of forearm, radial } \\
\text { head dislocation, hyperplastic callus } \\
\text { formation }\end{array}$ & Unknown & Not described \\
\hline OI VI & Unknown & $\begin{array}{l}\text { More fractures than OI type IV, vertebral } \\
\text { compression fractures, no DI }\end{array}$ & Unknown & Not described \\
\hline OI VII & $\begin{array}{r}\text { Autosomal } \\
\text { recessive }\end{array}$ & $\begin{array}{l}\text { Congenital fractures, blue sclerae, early } \\
\text { deformity of legs, coxa vara, osteopenia }\end{array}$ & Unknown & Not described \\
\hline
\end{tabular}

not be performed on amniocytes as they synthesize inadequate amounts of type I procollagen. Prenatal diagnosis by biochemical testing is not available for the identification of OI type I. The reduced synthesis of type I collagen chains typically seen in cells from individuals with OI type I cannot be detected reliably in CVS cells.

Mutation analysis can be performed for all types of OI, if the mutation in the family is known, using DNA extracted from CVS cells or amniocytes. The time from initial tissue sampling to test result is about $7-14$ days.

\section{In routine care of the pregnant woman with a negative family history of 01}

Ultrasound detection of skeletal anomalies may raise the suspicion of OI. When micromelia and undermineralization of the skeleton are found at 14-16 weeks gestation, the major differential includes OI type II, achondrogenesis types IA, IB and II, and autosomal recessive (severe infantile) hypophosphatasia (Table 2). In experienced centers, the sonographic evaluation will generally lead to a specific diagnosis. For most disorders, the gene(s) in which causative mutations lie are

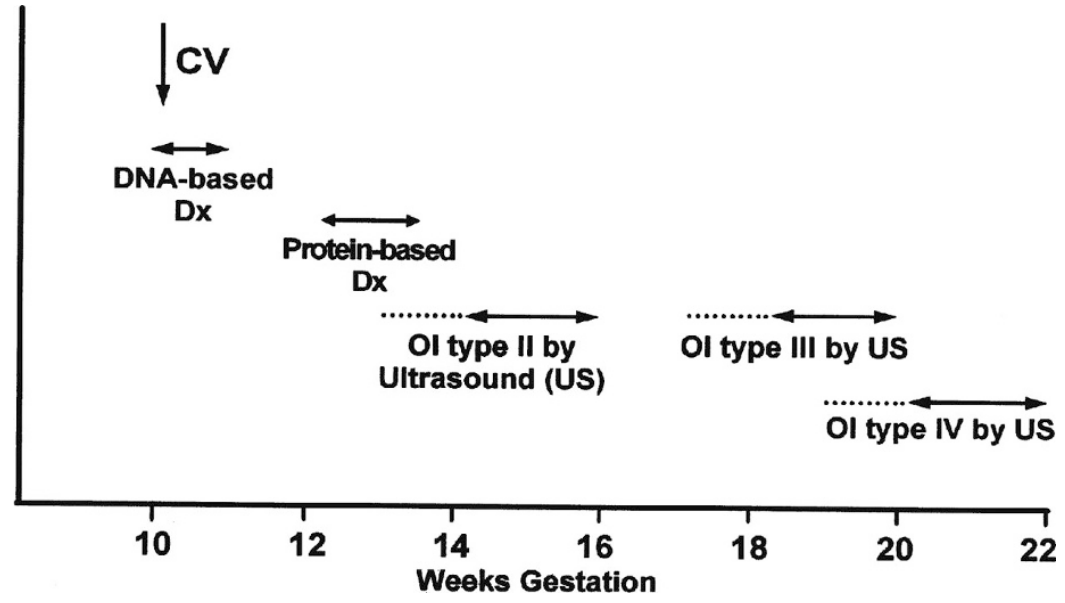

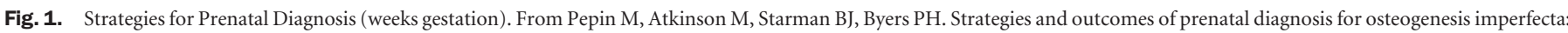
a review of biochemical and molecular studies completed in 129 pregnancies. Prenat Diagn 1997;17:559-570. ( ) John Wiley \& Sons Limited. Reproduced with permission. 
Table 2

Ultrasound differential diagnosis at $16-18$ weeks gestation

\begin{tabular}{|c|c|c|c|c|}
\hline Differential diagnosis & $\begin{array}{l}\text { Earliest ultrasound } \\
\text { identification }\end{array}$ & Genetics & Characteristics & Possible lab testing \\
\hline $\begin{array}{l}\text { OI type II lethal type } \\
1 / 60,000\end{array}$ & $14-16$ wks & $\mathrm{AD}$ & $\begin{array}{l}\text { Beaded ribs, micromelic limbs, fractures, } \\
\text { undermineralized skull }\end{array}$ & $\begin{array}{l}\text { COL1A1/COL1A2 mutation } \\
\text { identification }\end{array}$ \\
\hline $\begin{array}{l}\text { Achondrogenesis type } \\
\text { IB }\end{array}$ & 16 wks & $\mathrm{AR}$ & $\begin{array}{l}\text { Short limbs, short ribs, barrel shaped } \\
\text { thorax \& irregular scapulae, } \\
\text { undermineralized sacral bones \& } \\
\text { skull, short undermineralized } \\
\text { vertebral bodies }\end{array}$ & $\begin{array}{l}\text { Diastrophic dysplasia sulfate } \\
\text { transporter(DTDST) } \\
\text { gene mutation } \\
\text { identification }^{14}\end{array}$ \\
\hline $\begin{array}{l}\text { Achondrogenesis type } \\
\text { IA }\end{array}$ & $14-16$ wks & $\mathrm{AR}$ & $\begin{array}{l}\text { Short limbs, short ribs, splayed ends, rib } \\
\text { fractures, undermineralized bones and } \\
\text { skull, bowing, absent ossification of } \\
\text { vertebral bodies \& sacrum }\end{array}$ & Unknown \\
\hline $\begin{array}{l}\text { Achondrogenesis type } \\
\text { II }\end{array}$ & $14-16$ wks & $\mathrm{AD}$ & $\begin{array}{l}\text { Extreme micromelia, barrel shaped } \\
\text { thorax, undermineralized skull, } \\
\text { bowing, absent ossification vertebral } \\
\text { bodies \& sacrum }\end{array}$ & $\begin{array}{l}\text { COL2A1 mutation } \\
\text { identification } \\
15\end{array}$ \\
\hline $\begin{array}{l}\text { Perinatal/infantile } \\
\text { Hypophosphatasia } \\
(1 / 100,000)\end{array}$ & $14-16$ wks & $\mathrm{AR}$ & $\begin{array}{l}\text { Profound undermineralization of } \\
\text { skeleton, underossification of skull } \\
\text { and extremities, deformed limbs }\end{array}$ & TNSALP mutations $^{16}$ \\
\hline $\begin{array}{l}\text { Thamatrophoric } \\
\text { sydplasia }(1 / 30,000)\end{array}$ & 16 wks & $\mathrm{AD}$ & $\begin{array}{l}\text { Very short limgs, "telephone receiver } \\
\text { femurs." Normal mineralzation, } \\
\text { small chest }\end{array}$ & FGFR3 mutations ${ }^{17}$ \\
\hline
\end{tabular}

known but, because most mutations are unique to a family or individual, their identification may take several weeks. As a result, a discussion about pregnancy continuation or termination generally rests on sonographic evaluation (Table 2).

When termination is performed on the basis of ultrasound findings, the specific diagnosis, including OI, can be determined by biochemical study of cultured cells or analysis of DNA from the fetus. Detailed postmortem evaluation and $\mathrm{x}$-rays of the fetus are a necessary adjunct to diagnosis. If the pregnancy is continued to delivery, the genetic evaluation can be completed in the newborn period.

OI type III is seldom identified before 18 weeks gestation and confirmation of the diagnosis often requires serial ultrasounds to track evolving findings. The prenatal phenotype overlaps that of perinatal hypophosphatasia (frequency of $1 / 100,000$ ) (Table 3 ).

\section{OI: IDENTIFICATION IN CHILDHOOD}

In infancy and childhood, the clinical examination is the key first step in evaluation of the child with suspected OI. The evalu- ation requires familiarity with the natural history and variation in clinical presentation of OI, particularly in the infant or toddler. Mild forms of OI may go unnoticed by even experienced general clinicians. Referral to an experienced physician familiar with the range of clinical expression of OI (such as a medical geneticist) is relatively inexpensive in comparison to laboratory testing and may be all that is necessary to secure the diagnosis. There are several clinical circumstances that lead to the evaluation of a child for a brittle bone disorder such as OI.

\section{Family history of 0 이}

When a parent or relative is affected, the physical examination and radiographic findings in the child may be sufficient for clinical confirmation of OI. Exclusion of the diagnosis may be more difficult in individuals with mild forms. If the infant or toddler has few or equivocal findings, the clinician may adopt a wait and watch approach. If the family wishes to pursue prenatal diagnosis in a subsequent pregnancy, then laboratory testing (biochemical or DNA-based testing) is necessary.

Table 3

Ultrasound differential diagnosis at 18-20 weeks gestation

\begin{tabular}{lccc}
\hline Differential diagnosis & Gestational weeks & Genetics & Characteristics \\
\hline OI type III & $18-20 \mathrm{wks}$ & $\mathrm{AD}$ & $\begin{array}{l}\text { Shortened limbs, thin ribs, } \\
\text { fractures/angulation/bowing }\end{array}$ \\
Perinatal/infantile & $<20 \mathrm{wks}$ & AR & $\begin{array}{l}\text { Profound undermineralization } \\
\text { of skeleton, underossification } \\
\text { of skull and extremities, } \\
\text { deformed limbs }\end{array}$
\end{tabular}




\section{Frequent fractures}

At birth, OI types II and III are generally recognized on clinical and radiologic grounds and the clinical diagnosis is usually unequivocal. ${ }^{1}$ Genetic evaluation and counseling is recommended for confirmation and discussion about natural history, treatment and prenatal diagnosis in future pregnancies.

In childhood, in the absence of a positive family history, most children newly diagnosed with OI are identified after one or more fractures. The severity of the phenotype varies from the progressive deforming type (OI type III) to the mild phenotype of OI type I (see Table 3). The differential diagnosis for frequent fracture in childhood is relatively limited and in- cludes both inherited and acquired conditions. Hypophosphatasia, osteopetrosis with renal tubular acidosis, hypophosphatemic osteomalacia (rickets) and nonaccidental injury should be considered.

\section{Short stature, blue sclerae and dentinogenesis imperfecta (DI)}

Sometimes, the evaluation for OI in childhood is prompted by recognition of blue sclerae, conductive hearing loss, dentinogenesis imperfecta (DI) or during an evaluation for short stature. Blue sclerae are present in all children with OI type I and are, at times, dramatic. Roughly $20 \%$ of families with OI

Table 4

Clinical presentation and Genetic differential diagnosis of fractures in childhood

\begin{tabular}{|c|c|c|c|}
\hline Type & Inheritance & Clinical phenotype & Test \\
\hline OI type II & $\mathrm{AD}$ & $\begin{array}{l}\text { Lethal perinatal, undermineralized skull, beaded } \\
\text { ribs, compressed femurs, long bone } \\
\text { deformity, platyspondyly }\end{array}$ & Biochemical or Molecular \\
\hline OI type III & $\mathrm{AD} / \mathrm{AR}$ & $\begin{array}{l}\text { Progressively deforming bones, moderate } \\
\text { deformity at birth, sclerae hue varies, very } \\
\text { short stature, DI }\end{array}$ & Biochemical or Molecular \\
\hline OI type I & $\mathrm{AD}$ & $\begin{array}{l}\text { Fracture with little or no deformity, blue sclerae, } \\
\text { normal stature, hearing loss }\end{array}$ & Biochemical or Molecular \\
\hline OI type IV & $\mathrm{AD}$ & $\begin{array}{l}\text { Normal scleare, mild/moderate bone deformity } \\
\text { with fracture, variable short stature, DI, some } \\
\text { hearing loss }\end{array}$ & Biochemical or Molecular \\
\hline OI type V & $\mathrm{AD}$ & $\begin{array}{l}\text { Similar to OI IV plus calcification of } \\
\text { interosseous membrane of forearm, radial } \\
\text { head dislocation, hyperplastic callus } \\
\text { formation }\end{array}$ & Unknown \\
\hline OI type VI & $\mathrm{AD}$ or $\mathrm{AR}$ & $\begin{array}{l}\text { More fractures than OI IV, vertebral } \\
\text { compression fractures, no DI }\end{array}$ & Unknown \\
\hline OI type VII & $\mathrm{AR}$ & $\begin{array}{l}\text { Congenital fractures, blue sclerae, early } \\
\text { deformity of lower extremities, } \\
\text { coxa vara, osteopenia }\end{array}$ & Unknown \\
\hline $\begin{array}{l}\text { Hypophosphatasia, perinatal } \\
\text { and infantile form } \\
(1 / 100,000)\end{array}$ & $\mathrm{AR}$ & $\begin{array}{l}\text { Severe undermineralization, bone deformity, } \\
\text { fractures }\end{array}$ & TNSALP mutations \\
\hline $\begin{array}{l}\text { Hypophosphatasia } \\
\text { (childhood type) }\end{array}$ & $\mathrm{AD} / \mathrm{AR}$ & $\begin{array}{l}\text { Premature loss of teeth, rachitic bone changes, } \\
\text { fracture, undermineralization of bones }\end{array}$ & $\begin{array}{l}\text { Urinary } \\
\text { phosphoethanolamine, } \\
\text { plasma plasma ALP, } \\
\text { TNSALPL gene testing }\end{array}$ \\
\hline Juvenile Paget's disease & $\mathrm{AR}$ & $\begin{array}{l}\text { rapidly remodeling bone, osteopenia, fractures, } \\
\text { progressive skeletal deformity }\end{array}$ & TNFRSF11B mutations ${ }^{18}$ \\
\hline Bruck syndrome & $\mathrm{AR}$ & $\begin{array}{l}\text { Osteoporosis, joint contractures and fractures } \\
\text { and short stature }\end{array}$ & PLOD2 mutations ${ }^{19-21}$ \\
\hline $\begin{array}{l}\text { Osteopetrosis with renal } \\
\text { tubular acidosis }\end{array}$ & $\mathrm{AR}$ & $\begin{array}{l}\text { Before } 2 \text { years of age, fractures, short stature } \\
\text { and delayed development. RTA, cerebral } \\
\text { calcifications, mental retardation and dental } \\
\text { malocclusion }\end{array}$ & CAII mutations ${ }^{22}$ \\
\hline \multirow[t]{2}{*}{$\begin{array}{l}\text { Hypophosphatemic } \\
\text { osteomalacia "rickets" }\end{array}$} & \multirow[t]{2}{*}{$\mathrm{AD}, \mathrm{XLD}$} & \multirow[t]{2}{*}{$\begin{array}{l}\text { Before 2, osteomalacia and poor growth. } \\
\text { Later hypophosphatemia }\end{array}$} & $\begin{array}{l}\text { Low serum phosphorus, } \\
\text { elevated alk.phosphatase, } \\
\text { low urine calcium }\end{array}$ \\
\hline & & & FGF23, HYP genes ${ }^{23}$ \\
\hline Non-accidental injury & - & Unexplained fractures in infancy & \\
\hline
\end{tabular}


type I have DI. Infants and toddlers with OI type IV may have light blue sclerae and usually have DI, which may be subtle. Some children may be identified by short stature as about a third of individuals with OI type IV are less than the third percent for height in childhood (Table 4). ${ }^{9}$

\section{The infant or toddler with "unexplained fractures"}

In the first year of life, the presence of fractures for which an explanation is not provided or for which the stated mechanism of injury is not consistent with the fracture type raises a concern for nonaccidental injury (NAI). As NAI is the leading cause of fractures in infancy, a child abuse evaluation is warranted in such circumstances (http://nccanch.acf.hhs.gov/). If a biological basis for brittle bones is suspected and clinical examination is not definitive, then laboratory testing for OI and select metabolic bone disorders is generally appropriate.

On clinical examination, if an infant with unexplained fractures has few features of OI, as may be the case with OI type I, IV, V and VI, it may be difficult to confirm or exclude the diagnosis on the basis of family history, history and physical examination alone, particularly in the $0-8$ months age group.

Some clinical features of OI overlap with normal findings in infancy. For example: blue sclerae occur in normal infants before 12 months of age. However, with appropriate clinical evaluation, the diagnoses of OI type I and III are rarely in question. Infants with OI type IV, V and VI, with normal sclerae and normal length, may present only with fracture. Infants with OI can be missed on clinical evaluation and declared victims of NAI based on radiographic findings alone. ${ }^{10,11}$ Biochemical or DNA diagnostic testing, though not $100 \%$ sensitive, may be the best way to attempt to guard against these rare outcomes. ${ }^{10,11}$ When the index of clinical suspicion of OI is high, the physician may feel compelled to request testing to provide laboratory confirmation of the diagnosis in order to curtail additional Child Protective Services referrals.

The first studies ${ }^{10}$ evaluating the usefulness and sensitivity of collagen screening for identification of OI in children with unexplained fractures suggested that the physical examination by a clinician familiar with OI was as sensitive as biochemical diagnostic testing for identifying the child with OI. A recent review of biochemical testing completed on cells from 262 infants with OI versus infants with unexplained fractures described 3 children who were not identified as affected by comprehensive clinical evaluation in whom a type I collagen abnormality was detected on biochemical testing. The collagen abnormality identified in each instance was characteristic for OI - two with OI type I and one with OI type IV The clinical findings of the three infants in whom the clinical diagnosis of OI was not made could not be distinguished clinically from those who were positively identified by clinical examination. The expertise of the clinician and absence of any clinical findings were not contributing factors. ${ }^{11}$ Thus, in instances when the clinical diagnosis of OI is not apparent and the only feature of NAI present is unexplained fractures, lab testing may be the best way to provide the child and family with all possible safeguards.

\section{LABORATORY TESTING FOR OI}

Laboratory diagnosis of OI depends on the determination that cultured fibroblasts make either less type I procollagen than normal, make abnormal type I procollagen molecules or the identification of a mutation in COL1A1 or COL1A2, the two genes that encode the chains of type I procollagen. Collagen screening and DNA-based testing are available at the University of Washington (www.pathology.washington.edu/clinical/ collagen) and DNA-based testing is available at the Tulane University Matrix DNA Diagnostic Lab (http://www.som.tulane.edu/ gene_therapy/matrix/matrix_dna_diagnostics.shtml). Test sensitivity is high for both types of tests but it is not clear if the sensitivity is additive. ${ }^{12,13}$ Mutations in COL1A1 and COL1A2 do not cause OI type V, VI or VII, which account for about $8 \%$ of all children with OI.

\section{References}

1. Sillence DO, Senn A, Danks DM. Genetic heterogeneity in osteogenesis imperfecta. J Med Genet 1979;16:101-116.

2. Byers PH, Cole WJ. Osteogenesis imperfecta. In: Royce P, Steinmann B, editors. Connective tissue and its heritable disorders: molecular, genetic and medical aspects. New York: Wylie-Liss, 1979:385-430.

3. Glorieux FH, Rauch F, Plotkin H, Ward L, et al. Type V osteogenesis imperfecta: a new form of brittle bone disease. J Bone Miner Res 2000;15:1650-1658.

4. Glorieux FH, Ward LM, Rauch F, Lalic L, et al. Osteogenesis imperfecta type VI: a form of brittle bone disease with a mineralization defect. J Bone Miner Res 2002;17: 30-38.

5. Labuda M, Morissette J, Ward LM, Rauch F, et al. Osteogenesis imperfecta type VII maps to the short arm of chromosome 3. Bone 2002;31:19-25.

6. Pepin M, Atkinson M, Starman BJ, Byers PH. Strategies and outcomes of prenatal diagnosis for osteogenesis imperfecta: a review of biochemical and molecular studies completed in 129 pregnancies. Prenat Diagn 1997;17:559-570.

7. DiMaio MS, Barth R, Koprivnikar KE, Sussman BL, et al. First-trimester prenatal diagnosis of osteogenesis imperfecta type II by DNA analysis and sonography. Prenat Diagn 1993;13:589-596.

8. Sanders RC, Greyson-Fleg RT, Hogge WA, Blakemore KJ, et al. Osteogenesis imperfecta and campomelic dysplasia: difficulties in prenatal diagnosis. J Ultrasound Med 1994;13:691-700.

9. Paterson CR, McAllion SJ, Shaw JW. Clinical and radiological features of Osteogenesis imperfecta type IVA. Acta Peaediatr Scand 1987;76:548-552.

10. Steiner RD, Pepin M, Byers PH. Studies of collagen synthesis and structure in the differentiation of child abuse from osteogenesis imperfecta. J Pediatr 1996;128:542547.

11. Marlowe A, Pepin MG, Byers PH. Testing for osteogenisis imperfecta in cases of suspected non-accidental injury. J Med Genet 2002;39:382-386.

12. Wenstrup RJ, Willing MC, Starman BJ, Byers PH. Distinct biochemical phenotypes predict clinical severity in nonlethal variants of osteogenesis imperfecta. Am J Hum Genet 1990;46:975-982.

13. Korkko J, Ala-Kokko L, De Paepe A, Nuytinck L, et al. Analysis of the COL1A1 and COL1A2 genes by PCR amplification and scanning by conformation-sensitive gel electrophoresis identifies only COL1Al mutations in 15 patients with osteogenesis imperfecta type I: identification of common sequences of null-allele mutations. Am J Hum Genet 1998;62:98-110.

14. Hastbacka J, de la Chapelle A, Mahtani MM, Clines G, et al. The diastrophic dysplasia gene encodes a novel sulfate transporter: positional cloning by fine-structure linkage disequilibrium mapping. Cell 1994;78:1073-1087.

15. Chan D, Cole WG, Chow CW, Mundlos S, Bateman JF. A COL2A1 mutation in achondrogenesis type II results in the replacement of type II collagen by type I and III collagens in cartilage. J Biol Chem 1995;270:1747-1753.

16. Henthorn PS, Raducha M, Fedde KN, Lafferty MA, Whyte MP. Different missense mutations at the tissue-nonspecific alkaline phosphatase gene locus in autosomal recessively inherited forms of mild and severe hypophosphatasia. Proc Natl Acad Sci US A 1992;89:9924-9928.

17. Horton WA. Fibroblast growth factor receptor 3 and the human chondrodysplasias. Curr Opin Pediatr 1997;9:437-442.

18. Whyte MP, Obrecht SE, Finnegan PM, Jones JL, et al. Osteoprotegerin deficiency and juvenile Paget's disease. N Engl J Med 2002;347:175-184. 


\section{Byers et al.}

19. Bank RA, Robins SP, Wijmenga C, Breslau-Siderius LJ, et al. Defective collagen crosslinking in bone, but not in ligament or cartilage, in Bruck syndrome: indications for a bone-specific telopeptide lysyl hydroxylase on chromosome 17. Proc Natl Acad Sci U S A 1999;96:1054-1058.

20. van der Slot AJ, Zuurmond AM, Bardoel AF, Wijmenga C, et al. Identification of PLOD2 as telopeptide lysyl hydroxylase, an important enzyme in fibrosis. J Bio Chem 2003;278:40967-40972.
21. Ha-Vinh R, Alanay Y, Bank RA, Campos-Xavier AB, et al. Phenotypic and molecular characterization of Bruck syndrome (osteogenesis imperfecta with contractures of the large joints) caused by a recessive mutation in PLOD2. Am J Med Genet 2004; 131A:115-120.

22. Whyte MP. Carbonic anhydrase II deficiency. Clin Orthop Relat Res 1993;294:52-63

23. ADHR Consortium. Autosomal dominant hypophosphataemic rickets is associated with mutations in FGF23. Nat Genet 2000;26:345-348. 